\title{
KOMPARASI STRUCTURE EXERCISE METHOD DAN DRILL TERHADAP PEMAHAMAN KONSEP PADA MATERI STOIKIOMETRI
}

\author{
Ulvi Nikmawati $\mathbf{M}^{1)}$, Fitri Refelita ${ }^{2)}$, Arif Yasthophi ${ }^{3)}$ \\ 1) Program Studi Pendidikan Kimia Fakultas Tarbiyah dan Keguruan, \\ Universitas Islam Negeri Sultan Syarif Kasim Riau, Pekanbaru \\ Email: ulvinikmawatim@gmail.com \\ 2) Program Studi Pendidikan Kimia Fakultas Tarbiyah dan Keguruan, \\ Universitas Islam Negeri Sultan Syarif Kasim Riau, Pekanbaru \\ Email:refelitafitri@gmail.com \\ 3) Program Studi Pendidikan Kimia Fakultas Tarbiyah dan Keguruan, \\ Universitas Islam Negeri Sultan Syarif Kasim Riau, Pekanbaru \\ Email:arif.yasthophi@uin-suska.ac.id
}

\begin{abstract}
This research aimed at knowing whether there was or not a difference on student concept comprehension taught by using Guided Discovery Learning model with Structure Exercise method that was compared with taught by using Guided Discovery Learning model with Drill method on Stoichiometry. This study was conducted in SMA Negeri 1 Tambang in academic 2018/2019. This research was a Quasi-experiment with pretest and posttest design. Purposive sampling technique was used, and it was obtained two sample classes-the tenth-grade students of class MIA 2 (experimental class one) and MIA 3 (exsperimental class two). The data of observation results and student concept comprehension were tested by using independent sample t-test. Based on the data analysis, it was obtained $-t_{\text {table }} \leq t_{\text {observed }} \leq+t_{\text {table }}(-1.68<2.24>1.68)$. Thus, there was a significant difference on student concept comprehension between Guided Discovery Learning model with Structure Exercise and Guided Discovery Learning model with Drill method variables on Stoichiometry material at the tenth grade of State Senior High School 1 Tambang, mean score of student concept comprehension at the tenth grade of MIA 2 was 0.74 and the score of MIA 3 was 0.66 .
\end{abstract}

Keywords: Guided Discovery Learning, Structure Exercise Method, Drill Method, Student Concept Comprehension

\section{PENDAHULUAN}

Pendidikan merupakan hal yang penting untuk menunjukkan kemajuan dan eksistensi suatu bangsa yang menjadi tanggung jawab semua komponen bangsa itu. Kualitas pendidikan saat ini bisa dikatakan cukup rendah, karena masih banyak anak putus sekolah, sarana prasarana yang kurang memadai serta tidak meratanya pendidikan di Indonesia.

Pemahaman merupakan suatu proses yang terdiri dari kemampuan untuk menerangkan dan menginterpretasikan sesuatu, mampu

memberikan gambaran, contoh, dan penjelasan yang lebih luas dan memadai serta mampu memberikan uraian dan penjelasan yang kreatif, sedangkan konsep merupakan sesuatu yang tergambar dalam pikiran. Pemahaman konsep dapat diartikan sebagai proses berfikir seseorang untuk mengolah bahan ajar berupa informasi yang diterima sehingga menjadi bermakna. [1] Sehingga siswa dikatakan memiliki kemampuan pemahaman konsep jika ia dapat merumuskan strategi penyelesaian, 
menerapkan perhitungan sederhana, menggunakan simbol untuk mempresentasikan konsep, dan mengubah suatu bentuk ke bentuk yang lain. [2] Dijelaskan pada dokumen peraturan Dirjen Dikdasmen No. 506/C/PP/2004, indikator yang menunjukkan pemahaman konsep antara lain adalah: 1) menyatakan ulang sebuah konsep; 2) mengklasifikasikan objek menurut sifat-sifat tertentu; 3) memberi contoh dan noncontoh konsep;4) menyajikan konsep dalam berbagai bentuk representasi matematis;5) mengembangkan syarat perlu dan syarat cukup dari suatu konsep;6) menggunakan, memanfaatkan, dan memilih prosedur tertentu;7) mengaplikasikan konsep atau algoritma dalam pemecahan masalah [3]

Salah satu ilmu pengetahuan yang dipelajari di Sekolah Menengah Atas (SMA) adalah pelajaran kimia. Kimia sebagai bagian dari sains, yang menuntut pemahaman tingkat tinggi yang komprehensif untuk bisa memahaminya. Kimia mencangkup konsepkonsep yang sangat kompleks, bersifat abstrak dan banyak, sehingga tidak sedikit pembelajar yang menganggap kimia sebagai bidang ilmu yang sulit dipahami.[4]

Menurut Abdul Rahmat dan Irvin Novita Arifin menyatakan bahwa proses pembelajaran kimia yang masih konvensional seperti ceramah, sehingga proses pembelajaran disekolah cenderung berjalan satu arah. Guru lebih banyak yang aktif memberikan informasi kepada siswa dan siswa hanya bertindak sebagai agen belajar yang pasif. Ada juga anggapan siswa pembelajaran kimia dianggap membosankan. Kondisi seperti ini jelas tidak akan menumbuh kembangkan aspek kemampuan dan aktivitas siswa seperti yang diharapkan.

Salah satu materi kimia yang membutuhkan pemahaman tingkat tinggi adalah materi stoikiometri. Materi stoikiometri merupakan materi yang mendasari pokok bahasan lain dalam kimia, sehingga termasuk materi pembelajaran yang penting. Dalam mempelajari stoikiometri sering ditemukan siswa mengalami kesulitan dalam mengerjakan soal-soal perhitungan kimia. Stoikiometri merupakan materi yang sulit dikarenakan banyaknya konsep yang abstrak dan konsepkonsepnya yang berhubungan dengan rasio/proporsi reaktan maupun produk dalam perhitungan kimia sehingga menimbulkan miskonsepsi terhadap konsep stoikiometri tersebut. [5]

Berdasarkan observasi yang dilakukan pada pembelajaran kimia di SMAN 1 Tambang, didapatkan informasi bahwasanya masih ada siswa yang mengalami kesulitan belajar pada materi yang memerlukan pemahaman sehingga tidak tercapainya nilai kriteria ketuntasan minimum (KKM) yaitu 65. Hal ini dikarenakan pemahaman terhadap materi kurang dan kurang memahami rumus-rumus yang ada. Contohnya, Siswa kesulitan dalam memanipulasi angka maupun simbol.

Berdasarkan permasalahan yang diketahui,diperlukan perubahan dalam proses penyampaian materi kimia pada peserta didik disekolah. Hal ini sesuai dengan kurikulum 2013 pada permendikbud No.22 Th. 2016 menyatakan bahwa pada kegiatan inti pembelajaran menggunakan model pembelajaran, metode pembelajaran, media pembelajaran, dan sumber belajar yang disesuaikan dengan karakteristik peserta didik dan mata pelajaran. Dan salah satu model yang sesuai dengan pendekatan saintifik adalah model Guided Discovery Learning. Pembentukan konsep melalui model Discovery Learning didasari oleh tiga dasar teori, yaitu teori active learning John Dewey, teori processbased Jean Piaget, dan teori kognitif Vygotsky. Dewey menyatakan bahwa anak harus aktif, berkolaborasi, dan berpartisipasi dalam kelompok untuk dapat memahami sebuah situasi dengan baik. Piaget menyatakan bahwa pemahaman lahirnya dari discovery (proses menemukan), dan tanpa adanya keterlibatan siswa dalam membangun konsep dan memberinya kesempatan berpikir kreatif, maka pemahaman siswa hanya berupa pengulangan/hapalan saja. Sementara Vygotsky menyatakan bahwa proses pembentukan kognitif siswa dipengaruhi oleh interaksi siswa dengan orang lain.[6] Oleh karena itu peneliti tertarik menggunakan model Guided Discovery 
Learning. Guided Discovery Learning merupakan model pembelajaran yang melatih dan membimbing siswa untuk belajar, memperoleh pengetahuan, dan membangun konsep-konsep yang mereka temukan untuk diri mereka sendiri.

Dalam penemuan konsep yang ditemukan, karena materi stoikiometri merupakan materi perhitungan, oleh sebab itu diperlukan latihan yang terus menerus dan terstruktur. Ada beberapa metode latihan yang dapat digunakan seperti structure exercise method dan metode drill. Metode latihan berstruktur atau Structure exercise method dapat digunakan untuk meningkatkan pemahaman siswa mengenai suatu materi yang sedang dipelajari dengan adanya pemberian latihan soal-soal berstruktur, yaitu penggunaan soal-soal dengan tingkat kesulitan yang rendah dan dilanjutkan ke soal dengan tingkat kesulitan yang lebih tinggi.[7] Menurut Abdul Rahmat dan Irvin Novita Arifin bahwa Structure Exercise Method (SEM) merupakan salah satu alternatif metode yang dapat digunakan untuk meningkatkan aktivitas belajar dan hasil belajar sains peserta didik.

Metode drill merupakan suatu cara mengajar dengan memberikan latihan terhadap apa yang telah dipelajari siswa sehingga memperoleh keterampilan tertentu. [8] Melalui kegiatan pengulangan (repetisi) yang menjadi prinsip dari metode ini dapat membantu memori otak siswa untuk memahami dan mempertahankan informasi, pengetahuan, dan wawasan yang telah didapatkan.

Dari uraian diatas baik Structure Exercise Method dan metode drill merupakan metode latihan yang berdampak pada pemahaman konsep siswa. Oleh karena itu peneliti tertarik untuk mengangkat suatu penelitian yang berjudul "Komparasi Structure Exercise Method dan Drill terhadap Pemahaman Konsep Siswa pada Materi Stoikiometri.”

\section{METODE PENELITIAN}

Penelitian ini dilakukan pada 02 April-30 April 2018. Penelitian ini berlokasi di Sekolah Menengah Atas Negeri 1 Tambang Tahun Ajaran 2018/2019. Subjek penelitian ini adalah siswa dan siswi kelas X Sekolah Menengah
Atas Negeri 1 Tambang. Objek penelitian ini adalah studi komparasi model guided Discovery Learning dengan Structure Exercise Method dan Metode Drill terhadap Pemahaman Konsep Siswa Pada Materi Stoikiometri di Sekolah Menengah Atas Negeri 1 Tambang. Populasi yang disebutkan dalam penelitian ini adalah siswa kelas X Sekolah Menengah Atas Negeri 1 Tambang tahun ajaran 2018/2019 yang berada pada masa produktif terdiri dari 3 kelas.

Teknik pengambilan sampel yang digunakan adalah menggunakan purposive sampling. Kelas yang digunakan sebagai kelas eksperimen adalah kelas X MIA 2 dengan menggunakan model Model Guided Discovery Learning dengan Structure Exercise Method dan kelas yang digunakan sebagai kelas eksperimen 2 adalah kelas X MIA 3 dengan menggunakan Model Guided Discovery Learning dengan metode drill. Variabel bebas dalam penelitian ini adalah komparasi structure exercise method dan metode drill dan variabel terikatnya adalah pemahaman konsep siswa.

Untuk memudahkan pelaksanaan penelitian ini, disajikan prosedur atau tahapan yang tersusun sebagai berikut; 1) Observasi, 2) Analisis data awal, 3) Penyusunan instrumen penelitian, 4) Uji coba instrumen tes, 5) Pretest, 6) Pelaksanaan pembelajaran, 7) Posttest, 8) Analisis data, 9) Kesimpulan.

Teknik pengumpulan data yang digunakan berupa tes, observasi dan dokumentasi. Tes yang digunakan yaitu tes homogenitas, pretest dan posttest. Soal-soal tes yang diuji cobakan tersebut dianalisis untuk mengetahui validitas isi dan empiris, reliabilitas soal, tingkat kesukaran soal dan daya pembeda soal. Metode penelitian yang digunakan adalah metode quasi experiment dengan desain penelitian yang tercantum pada Tabel 1.

Tabel 1. Rancangan Penelitian pretest dan posttest

\begin{tabular}{cccc} 
Kelompok & Pretest & Perlakuan & Posttest \\
\hline $\begin{array}{c}\text { Eksperimen } \\
1\end{array}$ & $\mathrm{~T}_{1}$ & $\mathrm{X}_{1}$ & $\mathrm{~T}_{2}$ \\
\hline
\end{tabular}




\begin{tabular}{cccc}
\hline $\begin{array}{c}\text { Eksperimen } \\
2\end{array}$ & $\mathrm{~T}_{1}$ & $\mathrm{X}_{2}$ & $\mathrm{~T}_{2}$ \\
\hline
\end{tabular}

Keterangan :

$\mathrm{T}_{1} \quad$ : Tes sebelum diberikan pembelajaran pokok bahasan stoikiometri.

$\mathrm{X}_{1} \quad$ : Perlakuan terhadap kelas eksperimen dengan menggunakan model Guided Discovery Learning dengan Structure Exercise Method

$\mathrm{X}_{2} \quad$ : Perlakuan terhadap kelas eksperimen dengan menggunakan model Guided Discovery Learning dengan metode drill

$\mathrm{T}_{2} \quad$ : Tes setelah pembelajaran teknik stoikiometri.

Teknik analisis data terdiri dari uji homogenitas untuk data awal meng-gunakan uji Bartlet karena kelompok-kelompok yang dibandingkan mempunyai jumlah sampel yang tidak sama besar. Sebelum menganalisis data dengan uji $t$, maka data yang didapat harus dilakukan uji normalitas terlebih dahulu, uji normalitas digunakan untuk menguji apakah sampel dalam penelitian ini berasal dari populasi yang normal atau tidak, dengan menggunakan uji Chi Kuadrat $\left(\chi^{2}\right)$.[9] Untuk data akhir menggunakan tes " $t$ " Rumus tes " $\mathrm{t}$ " yang digunakan adalah independent. [10]

\section{HASIL DAN PEMBAHASAN}

Berdasarkan uji homogenitas dengan menggunakan uji Bartlet diperoleh tiga kelas yang homogen atau yang memiliki kemampuan yang sama, selanjutnya peneliti melakukan pemilihan sampel menggunakan teknik purposive sampling, di mana kelas X MIA 2 dipilih sebagai kelas eksperimen 1 dan kelas MIA 3 sebagai eksperimen 2. Untuk soal-soal tes yang digunakan setelah di analisis menggunakan validitas isi dan empiris, reliabilitas, tingkat kesukaran dan daya pembeda soal diperoleh 7 soal yang akan digunakan untuk pretest dan posttest.

Berdasarkan hasil analisis uji coba soal yang telah dilakukan, diperoleh bahwa untuk validitas isi dinyatakan $100 \%$ valid, sedangkan validitas empiris diperoleh 3 soal tidak valid dan 10 soal valid. Uji reliabilitas dilakukan dengan menggunakan rumus chi kuadrat diperoleh reliabilitas soal sebesar 0,7086 dengan kriteria sangat tinggi, sehingga soal memiliki keajegan yang tinggi. Tingkat kesukaran soal diperoleh $46 \%$ soal kategori mudah yang berjumlah 6 butir soal, 39\% soal kategori sedang yang berjumlah 5 butir soal dan $15 \%$ soal kategori sukar yang berjumlah 2 butir soal. Dengan demikian maka soal yang peneliti gunakan sebagai instrumen dalam penelitian ini adalah soal dengan kualitas yang baik dengan memakai pola perbandingan soal mudahsedang-sukar dengan 3-4-3. Daya pembeda soal diperoleh $8 \%$ dengan kriteria daya pembeda jelek yang berjumlah 1 soal, 38\% dengan kriteria daya pembeda cukup yang berjumlah 5 soal, $54 \%$ dengan kriteria baik yang berjumlah 7 soal, soal yang dijadikan instrumen dalam penelitian ini berjumlah 7 soal essay dengan kriteria daya pembeda cukup, baik sebagai soal pretest dan posttest.

Pada pertemuan ini, peneliti melaksanakan kegiatan pembelajaran berdasarkan kegiatan yang terdapat di dalam rencana pelaksanaan pembelajaran yaitu stoikiometri. Hasil perolehan rata-rata nilai LKPD untuk kelas eksperimen 1 lebih tinggi dibandingkan dengan nilai LKPD di kelas eksperimen 2. Rangkuman rata-rata nilai LKPD pada kelas eksperimen 1 dan kelas eksperimen 2 dapat dilihat pada Gambar 1.

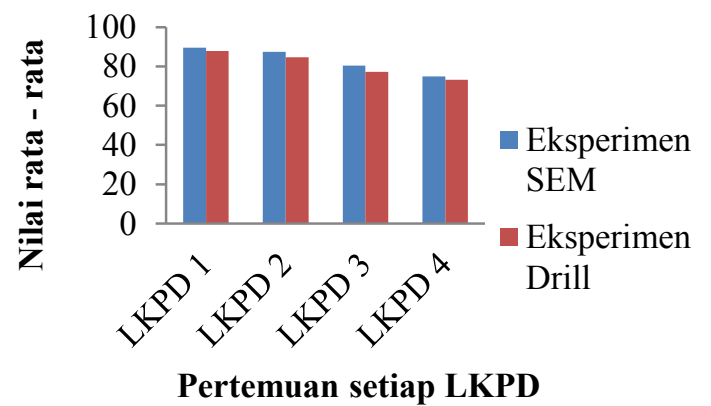

Gambar 1. Perbandingan rata-rata nilai LKPD kelas SEM dan Drill

Nilai rata-rata LKPD kelas eksperimen $S E M$ lebin tinggi dibanding kelas eksperimen 
Drill. Hal ini menandakan bahwa model Guided Discovery Learning dengan SEM lebih cocok pada materi stoikiometri.

Dilanjutnkan hasil perolehan rata-rata nilai evaluasi untuk kelas eksperimen 1 lebih tinggi dibandingkan dengan nilai evaluasi di kelas eksperimen 2. Rangkuman rata-rata nilai evaluasi pada kelas eksperimen 1 dan kelas eksperimen 2 dapat dilihat pada Gambar 2.

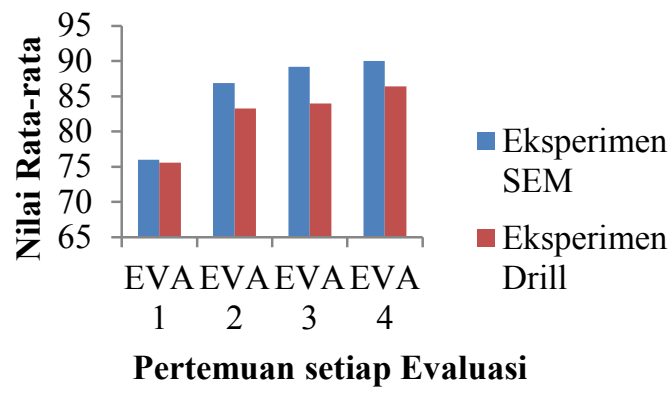

Gambar 2: Perbandingan rata-rata nilai evaluasi kelas SEM dan Drill

Terlihat rata-rata evaluasi kelas eksperimen SEM lebih tinggi dibandingkan kelas eksperimen Drill pada setiap pertemuan. Hal ini juga mengindikasikan bahwa siswa lebih memahami materi konsep mol dengan penerapan model Guided Discovery Learning dengan SEM daripada model Guided Discovery Learning dengan metode Drill.

Setelah diterapkan model Guided Discovery Learning dengan Structure Exercise Method pada kelas eksperimen 1 dan model Guided Discovery Learning dengan metode drill kelas eksperimen 2. maka dilakukanlah posttest. Nilai posttest masing-masing kelas mengalami peningkatan dari nilai pretest karena siswa sudah mempelajari materi yang terkait yaitus stoikiometri. Kelas eksperimen 1 memiliki nilai rata-rata posttest 81,44 dan kelas kontrol memiliki nilai rata-rata posttest 74,44.

Kelas eksperimen 1 memiliki nilai ratarata yang lebih tinggi dibandingkan dengan kelas eksperimen 2, sedangkan soal posttest yang diberikan adalah sama untuk kedua kelas tersebut yaitu 7 soal essay materi stoikiometri.
Perbandingan nilai pretest dan posttest kelas eksperimen dan kelas kontrol dapat dilihat Gambar 3.

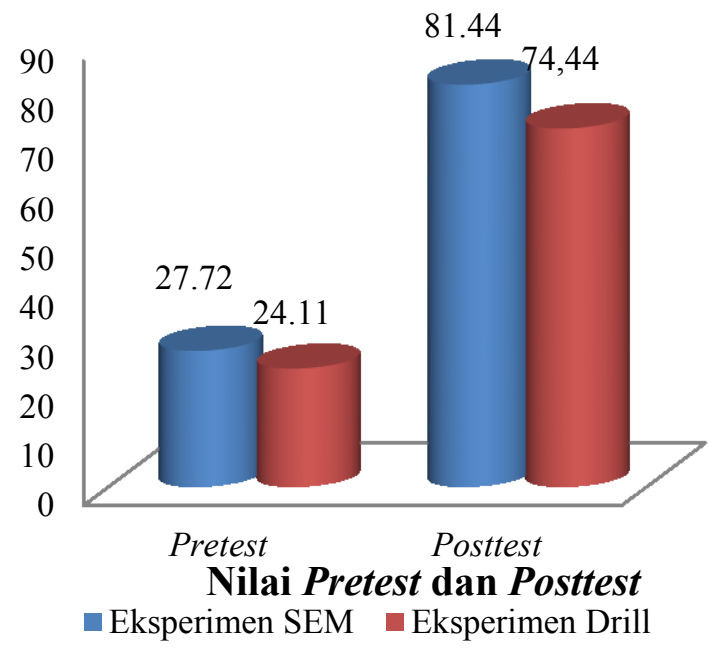

\section{Gambar 3. Perbandingan Rata-rata Pretest dan Posttest.}

Pembelajaran kimia dengan penerapan model Guided Discovery Learning dengan Structure Exercise Method dan model Guided Discovery Learning dengan metode Drill terdapat perbedaan yang signifikan pada pemahaman konsep siswa ada materi konsep mol. Hal ini terlihat dari selisih nilai posttest dan pretest kelas eskperimen SEM dan Drill.

Uji hipotesis yang digunakan pada penelitian ini adalah uji $\mathrm{t}$ dengan taraf signifikan 5\%. Uji hipotesis dapat dilakukan setelah data dinyatakan normal. Dari perhitungan uji $\mathrm{t}$ diperoleh $\mathrm{t}_{\text {hitung }}$ sebesar 2,28 dan setelah didistribusikan pada tabel t taraf signifikan $5 \%$ didapat harga $t_{\text {tabel }}$ sebesar 1,68. Jadi, setelah diperoleh $t_{\text {hitung }}>t_{\text {tabel }}(2,28>1,68)$ maka hipotesis nol $\left(\mathrm{H}_{0}\right)$ ditolak. Dengan demikian, rata-rata selisih nilai pretest dan posttest antara kelas eksperimen 1 dan kelas eksperimen 2 mengalami perbedaan.

Pembelajaran SEM yang dimulai dengan pemberian permasalahan berupa soal-soal latihan yang terstruktur dapat merangsang aktivitas siswa untuk menemukan pengetahuan secara mandiri. Hal ini sangat penting bagi pembelajaran agar peran guru tidak terlalu 
dominan di saat pembelajaran. Berbeda dengan metode Drill Method yang masih sangat memerlukan peran guru dalam penyampaian pengetahuan. pembelajaran mandiri dengan rangsangan soal-soal latihan berstruktur akan meningkatkan gairah siswa dalam memahami suatu materi. Hal ini dibuktikan dengan lebih tingginya nilai rata-rata eksperimen 1 dari kelas eksperimen 2.

perbedaan ini karena pada pembelajaran Guided Discovery Learning dengan Structure Exercise Method siswa benar-benar berinteraksi dalam diskusi dan dapat memicu siswa untuk saling bertukar fikiran. Dan dengan adanya latihan soal secara terstruktur mereka memang benar-benar tertantang dalam mengerjakan soal dari tingkatan soal rendah ke tingkatan soal yang tinggi. Hal ini sesuai dengan teori bahwasanya siswa menggunakan otak untuk berpikir, mengingat, menghafal, menghitung, menganalisis, bahkan mensintesis suatu informasi yang masuk kedalamnya. Proses belajar yang di dalamnya terjadi peristiwa berpikir dengan berlatih mendorong siswa untuk aktif (belajar aktif). Hal ini sesuai dengan pengajaran berdasarkan teori kognitif yang menekankan proses belajar aktif secara mental (melakukan proses mental, atau berpikir), di dalam mencari dan menemukan pengetahuannya.[11] Sedangkan pada model Guided Discovery Learning dengan metode drill kurangnya keantusiasan dan interaksi siswa dalam belajar. Dan dengan latihan soal secara berulang siswa menjadi jenuh dalam mengerjakannya.

Peningkatan pemahaman konsep dapat dilihat dari Tabel 2 dibawah ini.

\begin{tabular}{lcc}
\hline \multicolumn{2}{c}{ Persentase N-Gain } \\
\hline Kategori & $\begin{array}{c}\text { Kelas } \\
\text { Eksperimen 1 }\end{array}$ & $\begin{array}{c}\text { Kelas } \\
\text { Eksperimen 2 }\end{array}$ \\
\hline Tinggi & $64 \%$ & $44 \%$ \\
\hline Sedang & $36 \%$ & $56 \%$ \\
\hline Rendah & $0 \%$ & $0 \%$ \\
\hline
\end{tabular}

Tabel 2. Rekapitulasi $N$-Gain

Dalam penelitian ini peningkatan menggunakan $S E M$ jauh lebih baik dibanding metode Drill. Di mana Pengurutan penyampaian konsep dijelaskan Bruner dalam teori instruksinya, bahwa dalam mengajar siswa dibimbing melalui urutan pernyataanpernyataan dari suatu masalah atau sekumpulan pengetahuan untuk meningkatkan kemampuan siswa dalam menerima, mengubah, dan mentransfer apa yang telah dipelajarinya[12]

Menurut pendapat Rusmansyah soal-soal berjenjang yang diberikan kepada siswa dimulai dari soal-soal yang sederhana ke soal-soal yang lebih kompleks namun tetap dengan bimbingan dari guru. Guru terlebih dahulu memberikan contoh cara menyelesaikan soal secara berstruktur dengan baik sehingga siswa akan berlatih untuk menyelesaikan soal secara sistematis dan runtut. Jadi, pada kelas yang diajarkan dengan SEM siswa dibiasakan untuk berlatih menyelesaikan soal secara sistematis dan runtut (dimulai dari soal yang mudah, sedang hingga sulit) [13]

\section{KESIMPULAN}

Terdapat perbedaan model Guided Discovery Learning dan Strucure Exercise Method dibandingkan Guided Discovery Learning dengan Metode Drill terhadap pemahaman konsep siswa pada materi konsep mol di kelas X MIA SMA Negeri 1 Tambang. Dimana berdasarkan nilai $t_{\text {hitung }}>t_{\text {tabel }}$ dimana $t_{\text {hitung }}=2,28$ dan $t_{\text {tabel }} 1,68$.

\section{UCAPAN TERIMAKASIH}

Penelitian ini dapat selesai dengan baik karena bantuan dari berbagai pihak. Oleh karena itu penulis mengucapkan terimakasih kepada keluarga besar Program Studi Pendidikan Kimia Fakultas Tarbiyah dan Keguruan UIN Suska Riau yang telah memberikan ilmu yang sangat bermanfaat kepada penulis, Sekolah Menengah Atas Negeri 1 Tambang dan seluruh pihak yang terlibat yang telah membantu penulis dalam menyelesaikan penelitian ini.

\section{REFERENSI}

[1] Tilal Alfian, Muslimin Ibrahim Rudiana Agustini. 2014. Pengembangan Perangkat 
Pembelajaran Sains Berorientasi Guided Discovery Learning untuk Mengajarkan Kemampuan Berfikir kreatif dan Penguasaan Konsep. Jurnal Pendidikan Sains Pascasarjana Universitas Negeri Surabaya. Volume 4, Nomor 1

[2] Susanto, Ahmad. 2013. Teori Belajar \& Pembelajaran di Sekolah Dasar. Jakarta: PT Fajar Interpratama Mandiri.

[3] Sri Wardhani. 1984. Analisis SI dan SKL mata Pelajaran Matematika SMP/MTS Untuk Optimalisasi Pencapaian Tujuan. Yogyakarta : Pusat Pengembangan dan Pemberdayaan

[4] Abdul Rahmat dan Irvin Novita Arifin. 2016. Pengembangan Structure Exercise Method dalam Meningkatkan Hasil Belajar Sains pada Siswa di Madrasah Ibtidaiyah Al-Islah Gorontalo. Jurnal Nizham. Volume 3. Nomor 1

[5] Bayu Ishartono Ashdi dan Endang Susilowati. 2015. Implementasi Model Pembelajaran Problem Solving Berbantuan Peer Tutoring Dilengkapi Hierarki Konsep Untuk Meningkatkan Kualitas Proses Dan Hasil Belajar Materi Stoikiometri Pada Siswa Kelas X IPA 6 SMAN 1 Sukoharjo Tahun Pelajaran 2013/2014. Jurnal Pendidikan Kimia. Volume 4 Nomor 1.

[6] Afriana Nur Kholifah, Yudi Rinanto, Murni Ramli. 2015. Kajian Penerapan Model Guided Discovery Learning Disertai Concept Map Terhadap Pemahaman Konsep Siswa Kelas XI Pada Materi Sistem Imun. Jurnal Bio- Pedagogi. Volume 4. Nomor 1

[7] Fanny Firmansyah, Antonius Tri Widodo dan Sri Nurhayati. 2014. Pengaruh Model Team Assisted Individualization dengan Structure Exercise Method Terhadap Hasil Belajar. Jurnal Inovasi Pendidikan Kimia. Volume 8, Nomor 1

[8] Erny Susilowati, Sigit Santoso, Nurhasan Hamidi. 2013. Penggunaan Metode
Pembelajaran Drill Sebagai Upaya Meningkatkan Prestasi Belajar Akuntansi. Jupe UNS, Volume 1, Nomor. 3.

[9] Yulistyana, P, Bakti, M, dan Tri, R. 2015. Penerapan Model Pemebelajaran Project Based Learning untuk Meningkatkan Prestasi Belajar dan Kreativitas Siswa Pada Materi Pokok Sistem Koloid Kelas XI IPA Semester Genap Madrasah Aliyah Negeri Klaten Tahun Pelajaran 2013/2014. Jurnal Pendidikan Kimia, Surakarta, ISSN: 2337-9995. Vol. 4 No. 1.

[10] Sugiyono.2014. Statistik Untuk Penelitian. Bandung: Alfabeta

[11] Nana Syaodih dan Ibrahim R. 2003. Perencanaan Pengajaran. Jakarta : Rineka Cipta.

[12] Ratna Wilis Dahar. 1989. Teor-teori Belajar. Jakarta. Erlangga

[13]Rusmansyah dan Irhasyuarna. 2007. Penerapan Metode Latihan Berstruktur dalam Meningkatkan Pemahaman Siswa Terhadap Konsep Persamaan Reaksi Kimia. Banjarmasin: PMIPA Unlam. Volume 2 nomor 2 